\title{
Evaluation of prebiotic activity of conventional fibre feedstuffs in the diets of pigs
}

*Ogunjobi, F. V., ${ }^{1}$ Adeyemi, M. A. and Akinfala, E. O. Department of Animal Sciences, Obafemi Awolowo University, Ile-Ife

${ }^{I}$ Department of Animal Production and Health, Olusegun Agagu University of Science and Technology, Okitipupa

*Corresponding author: fvogunjobi@gmail.com

Abstract

Over the years, significant research efforts have been made to improve livestock welfare and productivity. In part, this has been achieved through the use of in-feed antibiotics to enhance production and maintain animal health. More recently, the risks of residual effects, cross-resistance and development of antibacterial resistant strains especially on animal and final consumers of animal products provided justification for prohibition, hence the continuous search for suitable and costeffective alternatives. This study evaluated the prebiotic activity of four fibre feedstuffs in diets of pigs. Twenty growing crossbred (Large White $\times$ Hampshire) pigs with a mean weight of $40 \pm 0.50 \mathrm{Kg}$ were randomly allotted to four fibre feedstuffs namely palm kernel cake (PKC), brewer's dried grain (BDG), wheat offal (WO) and rice bran (RB) as well as maize in a 14-day feeding trial to examine their effect on the growth of non-pathogenic gut microbiota. The experimental pigs were randomly allocated to the diets in a completely randomized design with four animals per treatment. The arabinoxylanoligosaccharide concentrations, proximate and cell wall composition of fibre feedstuffs, short chain fatty acids concentrations, apparent nutrient digestibility in the experimental animals, and the activities of bacteria in the guts of the experimental pigs were evaluated. Results showed significant difference $(p<0.05)$ in arabinoxylan-oligosaccharide concentration among treatment groups. The short chain fatty acids $(S C F A s)$ concentrations were significantly $(p<0.05)$ affected by fibre sources both at the foregut and hindgut of pigs. Also, the SCFAs concentrations produced in the hindgut were numerically $(p>0.05)$ higher compared to the values in the foregut of pigs. The results also demonstrated that acetate and butyrate were mainly produced in the foregut while the concentration of propionate in addition to butyrate increased in the hindgut of pigs. The digesta acetate concentration was negatively correlated with dietary acid detergent fibre (ADF) and cellulose in the foregut. All the fibre feedstuffs promoted the growth of non-pathogenic Lactobacillus than maize in the foregut and hindgut, hence, palm kernel cake, brewer dried grains, wheat offal and rice bran could elicit prebiotic activity in the gut of growing pigs and enhance animal welfare.

Keywords: antibiotics; prebiotic; fibre feedstuffs; short chain fatty acids; animal welfare

\section{Évaluation de l'activité pré biotique des aliments à base de fibres conventionnels dans} l'alimentation des porcs

\section{Résumé}

Au fil des ans, des efforts de recherche importants ont été faits pour améliorer le bien-être et la productivité du bétail. En partie, cela a été réalisé grâce à l'utilisation d'antibiotiques dans l'alimentation pour améliorer la production et maintenir la santé animale. Plus récemment, les risques d'effets résiduels, de résistance croisée et de développement de souches antibactériennes résistantes en particulier sur les animaux et les consommateurs finaux de produits animaux ont justifié l'interdiction, d'où la recherche continue d'alternatives adaptées et rentables. Cette étude a évalué l'activité prébiotique de quatre aliments à base de fibres dans l'alimentation des porcs. Vingt porcs croisés en croissance (Large White $\times$ Hampshire) d'un poids moyen de $40 \pm 0,50 \mathrm{~kg}$ ont été attribués au hasard à quatre aliments à base de fibres, à savoir le tourteau de palmiste (PKC), les céréales séchées de brasserie $(B D G)$, les abats de blé (WO) et le son de riz ( $R B)$ ainsi que du maïs dans un essai d'alimentation de 14 jours pour examiner leur effet sur la croissance du microbiote intestinal non pathogène. Les porcs expérimentaux ont été répartis au hasard dans les régimes alimentaires dans une conception complètement aléatoire avec quatre animaux par traitement. Les concentrations 


\section{Evaluation of prebiotic activity of conventional fibre feedstuffs in the diets of pigs}

d'arabinoxylane-oligosaccharide, la composition proximale et de la paroi cellulaire des aliments à base de fibres, les concentrations d'acides gras à chaîne courte, la digestibilité apparente des nutriments chez les animaux de laboratoire et les activités des bactéries dans les intestins des porcs expérimentaux ont été évaluées. Les résultats ont montré une différence significative ( $p$ $<0,05)$ dans la concentration d'arabinoxylane-oligosaccharide entre les groupes de traitement. Les concentrations d'acides gras à chaîne courte (AGCC) étaient significativement affectées ( $p$ $<0,05)$ par les sources de fibres tant au niveau de l'intestin antérieur que de l'intestin postérieur des porcs. De plus, les concentrations de SCFA produites dans l'intestin postérieur étaient numériquement $(p>0,05)$ plus élevées que les valeurs dans l'intestin antérieur des porcs. Les résultats ont également démontré que l'acétate et le butyrate étaient principalement produits dans l'intestin antérieur tandis que la concentration de propionate en plus du butyrate augmentait dans l'intestin postérieur des porcs. La concentration en acétate de digesta était négativement corrélée avec les fibres de détergent acide alimentaire (ADF) et la cellulose dans l'intestin antérieur. Tous les aliments à base de fibres ont favorisé la croissance de Lactobacillus non pathogènes que le maïs dans l'intestin antérieur et l'intestin postérieur, par conséquent, le tourteau de palmiste, les céréales séchées de brasserie, les abats de blé et le son de riz pourraient provoquer une activité prébiotique dans l'intestin des porcs en croissance et améliorer le bienêtre animal.

Mots clés: antibiotiques; prébiotique; aliments à base de fibres; acides gras à chaîne courte; bienêtre animal

\section{Introduction}

The use of antibiotics over the last few decades especially in enhancing performance of pigs has gained relevance due to its effects on animal health and wellbeing as well as enhancing the economy of farmers (Cromwell, 2000; Anderson et al., 2000; Patterson, 2005). However, the rising cases in the risks of residual effects, crossresistance and development of antibacterial resistant strains especially on animal and final consumers of animal products provided justification for its prohibition (Phillips, 1999; Fernando et al., 2007; EFSA, 2009). Sequel to this development, dietary approaches had been adopted in livestock industry as prophylactic means in the control of diseases and pathogens and with the capacity to enhance growth and proliferation of beneficial flora at the same time, inhibiting growth of pathogenic bacteria in the gut. These alternatives are targeted towards the possibility of promoting growth and general well-being of pigs in place of the synthetic antibiotics (Patterson, 2005; Bach Knudsen et al.,
2012). One of such strategy is the incorporation of dietary fibre (DF). Studies by Bedford and Schuzle (1998) showed that DF has lower nutritive value for monogastrics, including pigs owing to its non-digestible nature. Nonetheless, DF has received numerous attentions lately in pig nutrition due to its beneficial effects when fermented in the gut (Bach Knudsen et al., 2012) as such stimulates the growth of beneficial bacterial species such as Bifidobacteria and Lactobacilli (Williams et al., 2001) at the expense of pathogenic Clostridium or Salmonella. Also, the proliferation of cellulolytic bacteria has been reported (Bouhnik et al., 2004; Bindelle et al., 2010) to enhance hind gut fermentation and production of volatile fatty acids (VFAs) as well as decrease the $\mathrm{pH}$ of the gut contents, thus, contribute to enhancing the health of host species. This activity was termed 'prebiotic effect' by Gibson and Roberfroid (1995).

The prebiotic potentials of fibre feedstuffs in the diets of pigs have been studied by several researchers (Roberfroid et al., 2001; 
Shim et al., 2005; Pieper et al., 2008; Nielsen et al., 2014) through evaluation of gut microbial activity and production of VFAs. Also, several feed oligosaccharides such as fructans and inulin, and polysaccharides such as arabinoxylans and mannans have been reported (Grizard and Barthomeuf, 1999; Roberfroid et al., 2001; Tuohy et al., 2005; Vondruskova et al., 2010) to have prebiotic activity, but not all dietary carbohydrates are prebiotics.

In addition, different fibre sources have different prebiotic activities due to their varying components. However, there exists limited information on prebiotic activity in the digesta of pigs fed fibre feedstuffs such as palm kernel cake (PKC), brewer's dried grain (BDG), wheat offal (WO) and rice bran (RB) which form the bulk of swine diets in Nigeria. To this, the objective of this study was conceived and aimed at evaluating the prebiotic activities of fibre feedstuffs fed to growing pigs.

\section{Materials and methods}

\section{Experimental location and source of test ingredients}

The study was carried out at the Swine Unit of the Teaching and Research Farm, Obafemi Awolowo University (OAU), IleIfe, Nigeria. The OAU is located within the rainforest zone, Latitude $7^{\circ} 28^{\prime} \mathrm{N}$ and Longitude $4^{\circ} 33^{\prime} \mathrm{E}$ at an elevation of about $200 \mathrm{~m}$ above sea level. Test ingredients (palm kernel cake, brewers' dried grain, wheat offal, rice bran and maize) were purchased from a commercial feed mill in Ile-Ife, Osun State, Nigeria.

Experimental diets, design and management of experimental pigs

Five experimental diets containing $97 \%$ each of maize, palm kernel cake, brewer dried grain, wheat bran and rice bran balanced with $3 \%$ vitamins and minerals were formulated for the experimental pigs (Table 1). Twenty growing crossbred (Large White x Hampshire) pigs each of average initial weight of $20 \pm 0.50 \mathrm{Kg}$ and $40 \pm 0.50 \mathrm{Kg}$ were used for the digestibility trial and prebiotic activities, respectively. The animals were randomly distributed to the five diets in a completely randomized design (CRD). There were two replicates per treatment, with two animals in each replicate. The animals were acclimatized for 14 days, fed and watered ad libitum. Routine management practices were carried out on daily basis. Ivomectin injection was administered on the animal on day 3 of the adaptation period. The experimental pigs received humane handling and care, and their use was approved by the animal ethical Committee of the OAU, Ile-Ife.

Chemical analysis of test ingredients, faecal samples and digesta contents

The arabinoxylan-oligosaccharide concentrations of the different fibre feedstuffs and maize were determined using the procedure of Jahromi et al. (2016) and the percentage arabinoxylanoligosaccharide concentration was calculated using the equation:

$\%$ Arabinoxylan (AX)-oligosaccharide = Absorbance of sample $x$ average gradient factor $\times \mathrm{df} \times 100 \%$ weight of sample

$\mathrm{df}=$ dilution factor

Proximate composition and cell wall fractions of the test ingredients were carried out using the procedures outlined by A.O.A.C. (2005) and Van Soest et al. (1991), respectively.

Apparent nutrient digestibility trial was carried out after the acclimatisation period. A total of 20 experimental pigs with average initial weight of $20 \pm 0.50 \mathrm{Kg}$ were kept in locally fabricated metabolic cages of 107 $\mathrm{cm}$ x $60 \mathrm{~cm}$ x $50 \mathrm{~cm}$ dimension for a period of 10 days. The experimental pigs were fed at 0800 hours with daily ration allocation of $5 \%$ body weight while fresh and cool water was supplied ad libitum. Faecal collection was done on the last three days of the experiment and each collection was oven 
Table 1: Composition of experimental diets

\begin{tabular}{llllll}
\hline Parameters & $\begin{array}{l}\text { Diets } \\
\text { Maize }\end{array}$ & PKC & BDG & WO & RB \\
\hline Maize & 97.0 & - & - & - & - \\
Palm kernel cake & - & 97.0 & - & - & - \\
Brewer dried grains & - & - & 97.0 & - & - \\
Wheat bran & - & - & - & 97.0 & - \\
Rice bran & - & - & - & - & 97.0 \\
Bone meal & 2.5 & 2.5 & 2.5 & 2.5 & 2.5 \\
Vitamin-mineral premix & 0.25 & 0.25 & 0.25 & 0.25 & 0.25 \\
Salt & 0.25 & 0.25 & 0.25 & 0.25 & 0.25 \\
Total & $\mathbf{1 0 0 . 0}$ & $\mathbf{1 0 0 . 0}$ & $\mathbf{1 0 0 . 0}$ & $\mathbf{1 0 0 . 0}$ & $\mathbf{1 0 0 . 0}$ \\
Calculated Analysis & & & & & \\
ME (Kcal/Kg) & 3329.04 & 2619.0 & 2437.61 & 1218.32 & 1835.24 \\
Crude Protein & 8.63 & 18.24 & 27.06 & 15.14 & 7.61 \\
Calcium & 0.98 & 1.14 & 1.19 & 0.14 & 0.96 \\
Phosphorus & 0.70 & 1.13 & 1.27 & 1.16 & 2.17 \\
Lysine & 0.25 & 0.60 & 0.87 & 0.78 & 0.50 \\
Methionine & 0.20 & 0.47 & 0.58 & 0.19 & 0.23 \\
Crude fibre & 2.62 & 10.67 & 11.35 & 6.80 & 11.64 \\
\hline
\end{tabular}

PKC - Palm kernel cake, BDG - Brewer's dried grain, WO - Wheat offal and RB - Rice bran

Table 2: Oligosaccharide, proximate and Cell wall contents of maize and fibre feedstuffs

\begin{tabular}{|c|c|c|c|c|c|c|c|}
\hline \multirow[b]{2}{*}{ Parameters (\%) } & \multicolumn{3}{|c|}{ Diets } & \multirow[b]{2}{*}{ WO } & \multirow[b]{2}{*}{ RB } & \multirow[b]{2}{*}{ SEM } & \multirow[b]{2}{*}{ p-value } \\
\hline & Maize & PKC & BDG & & & & \\
\hline \multicolumn{8}{|c|}{ Oligosaccharide concentrations } \\
\hline AX-oligo & $0.50^{\mathrm{e}}$ & $1.00^{\mathrm{a}}$ & $0.81^{\mathrm{b}}$ & $0.58^{\mathrm{d}}$ & $0.65^{\mathrm{c}}$ & 0.06 & $<0.01$ \\
\hline \multicolumn{8}{|c|}{ Proximate composition } \\
\hline Dry Matter & $89.45^{b}$ & $91.94^{\mathrm{a}}$ & $87.50^{\mathrm{d}}$ & $88.88^{c}$ & $92.12^{\mathrm{a}}$ & 0.48 & $<0.01$ \\
\hline Crude protein & $8.97^{\mathrm{d}}$ & $20.78^{\mathrm{b}}$ & $26.47^{\mathrm{a}}$ & $17.28^{\mathrm{c}}$ & $7.88^{\mathrm{d}}$ & 1.89 & $<0.01$ \\
\hline Crude Fibre & $1.99^{\mathrm{e}}$ & $12.06^{\mathrm{c}}$ & $15.04^{\mathrm{b}}$ & $7.01^{\mathrm{d}}$ & $27.50^{\mathrm{a}}$ & 2.32 & $<0.01$ \\
\hline Ether Extract & $3.89^{\mathrm{cd}}$ & $6.18^{\mathrm{a}}$ & $4.08^{c}$ & $3.53^{\mathrm{d}}$ & $5.12^{\mathrm{b}}$ & 0.26 & $<0.01$ \\
\hline Ash & $3.98^{\mathrm{e}}$ & $6.02^{\mathrm{d}}$ & $10.23^{b}$ & $7.05^{\mathrm{c}}$ & $20.51^{\mathrm{a}}$ & 1.56 & $<0.01$ \\
\hline NFE & $70.62^{\mathrm{a}}$ & $46.90^{c}$ & $31.68^{\mathrm{d}}$ & $54.00^{\mathrm{b}}$ & $31.13^{\mathrm{d}}$ & 3.96 & $<0.01$ \\
\hline \multicolumn{8}{|l|}{ Cell wall composition } \\
\hline $\begin{array}{l}\text { Neutral Detergent } \\
\text { Fibre }\end{array}$ & $26.18^{\mathrm{e}}$ & $58.21^{\mathrm{c}}$ & $62.03^{\mathrm{b}}$ & $39.69^{\mathrm{d}}$ & $69.27^{\mathrm{a}}$ & 4.24 & $<0.01$ \\
\hline Acid Detergent Fibre & $4.66^{\mathrm{e}}$ & $41.37^{\mathrm{b}}$ & $33.20^{\mathrm{c}}$ & $10.48^{\mathrm{d}}$ & $50.31^{\mathrm{a}}$ & 4.73 & $<0.01$ \\
\hline Acid Detergent & $0.25^{\mathrm{e}}$ & $12.52^{\mathrm{a}}$ & $7.72^{\mathrm{c}}$ & $2.63^{\mathrm{d}}$ & $9.46^{\mathrm{b}}$ & 1.20 & $<0.01$ \\
\hline \multicolumn{8}{|l|}{ Lignin } \\
\hline Cellulose & $4.42^{\mathrm{c}}$ & $28.86^{\mathrm{b}}$ & $25.48^{\mathrm{b}}$ & $7.86^{\mathrm{c}}$ & $40.85^{\mathrm{a}}$ & 3.66 & $<0.01$ \\
\hline Hemicellulose & $21.52^{\mathrm{b}}$ & $16.84^{\mathrm{c}}$ & $28.83^{\mathrm{a}}$ & $29.21^{\mathrm{a}}$ & $18.96^{\mathrm{c}}$ & 1.39 & $<0.01$ \\
\hline
\end{tabular}




\section{Ogunjobi, Adeyemi and Akinfala}

dried, kept in plastic and stored in freezer at $-4^{\circ} \mathrm{C}$. Total oven dried faeces collected was bulked, weighed, thoroughly mixed and ground, while representative samples were taken for proximate analysis following the procedure of AOAC (2005). Apparent nutrient digestibility of the fibre feedstuffs by the pigs was determined using the equation:

Nutrient in feed-Nutrient in faece x $100 \%$ Nutrient in feed

The experimental trial for prebiotic activity of fibre feedstuffs was carried out for 14 days during which the experimental pigs were fed experimental diets ad libitum. At the end of the feeding trial, one animal per replicate were randomly selected and slaughtered traditionally. The gastrointestinal tract of each pig was removed and kept in a clean container while the digesta of the foregut (jejunum, duodenum and ileum) and hindgut (caecum and colon) were collected separately into sterile sample bottles to determine the short chain fatty acids (SCFAs) and microbial count using the procedure described by Kalantar et al. (2014). The pH was determined immediately while samples were frozen for determination of SCFA using the method of Gancarcikova et al. (2009). Triplicate samples of the SCFAs (acetic, propionic and butyric acids) were quantified using the method of Jouany (1982) while SCFAs were analyzed in the supernatants using high performance liquid chromatography (HPLC) following the procedure of Wang et al. (2005). The concentrations of SCFAs were assayed using HPLC (Agilent 2890B) with a $\mathrm{C}_{18}$ column. For microbial count analysis, $1 \mathrm{~g}$ of each sample was measured into a macCarthney bottle containing $10 \mathrm{ml}$ sterile water and shaken thoroughly. Five times hundred folds of serial dilution was carried out in a set of test tubes containing $9.9 \mathrm{ml}$ sterile distilled water. Cultured samples were prepared by pipetting $1 \mathrm{~mL}$ of each diluted sample on sterile petri dishes in triplicates using the pour plate technique. The cultured plates with nutrient agar and De-Man, Rogosa and Sharpe agar (MRS) were incubated invertedly and aerobically at $35^{\circ} \mathrm{C}$ for 48 hours to enumerate for only aerobes/ facultative heterotrophic bacteria and Lactobacillus bacteria respectively. The cultured plates were observed for growth and count after the expiration of the incubation period.

\section{Statistical analysis}

Data were subjected to Analysis of Variance (ANOVA) using the SAS (2009) package. Statistical significance was assessed at $p$ $<0.05$ (95\% confidence) while differences in mean was separated using Duncan's Multiple Range Test.

\section{Results}

The arabinoxylan-oligosaccharide concentrations, proximate and cell wall compositions of maize and different fibre feedstuffs are shown in Table 2. There were significant $(p<0.05)$ differences in the arabinoxylan-oligosaccharide concentrations across treatments. The arabinoxylan-oligosaccharide concentrations of fibre feedstuffs (PKC, $\mathrm{BDG}, \mathrm{WO}$ and $\mathrm{RB}$ ) with respect to maize were $200 \%, 162 \%, 116 \%$ and $130 \%$ higher, respectively. The values obtained for the proximate content of fibre feedstuffs and maize showed significant differences $(p<0.05)$ in all measured parameters. The BDG had higher crude protein (CP) content of $26.47 \%$ compared to maize while PKC, WO and RB had $56.83 \%, 48.09 \%$ and $0.14 \%$ higher CP content than maize. Similarly, the crude fibre (CF) contents of $\mathrm{RB}, \mathrm{BDG}, \mathrm{PKC}$ and $\mathrm{WO}$ in relation to maize were $92.76 \%, 86.77 \%, 83.50 \%$ and $71.61 \%$ higher respectively and differed $(\mathrm{p}<0.05)$ across treatment groups. 
The values obtained for all the cell wall composition of maize and fibre feedstuffs were significantly different $(p<0.05)$ across treatment groups (Table 2). The neutral detergent fibre content was least in maize but the values obtained for fibre feedstuffs appear to increase across treatment groups from PKC to RB except in WO which had $34.04 \%$ higher NDF content compared to maize. For PKC, BDG and RB, they had $55.02 \%, 57.79 \%$ and $62.20 \%$ higher NDF content compared to maize. Also, the lignin content of PKC, RB, BDG and $\mathrm{WO}$ in relation to maize were $98 \%, 97.36 \%$, $96.76 \%$ and $90.49 \%$ higher respectively. Similarly, the cellulose fraction of the fibre feedstuffs appears to follow same trend as lignin, except for WO which was $29.35 \%$ higher than the value obtained for PKC. The hemicellulose contents of WO and
BDG were $26.33 \%$ and $25.36 \%$ respectively higher than the value obtained for maize while PKC and RB had $20.75 \%$ and $11.90 \%$ lower values, respectively.

The results of apparent nutrient digestibility in pigs fed maize and fibre feedstuffs (Table 3) showed that pigs on RB had significantly lower values $(\mathrm{p}<0.05)$ in two-thirds (dry matter, crude protein, ash, neutral detergent fibre, acid detergent fibre and hemicellulose) of all evaluated parameters. Pigs fed BDG diet had the least coefficient of digestibility for acid detergent lignin $(p<0.05)$ than those fed maize. The coefficient of cellulose digestibility was highest $(p<0.05)$ in pigs fed PKC while pigs on maize and other fibre feedstuffs (WO, BDG and RB) were $9.68 \%, 64.39 \%, 45.58 \%$ and $68.94 \%$, respectively lower than those on PKC diet.

Table 3: Apparent nutrient digestibility of chemical components for pig fed different fibre feedstuffs

\begin{tabular}{|c|c|c|c|c|c|c|c|}
\hline Parameters (\%) & $\begin{array}{l}\text { Diets } \\
\text { Maize }\end{array}$ & PKC & BDG & WO & RB & SEM & p-value \\
\hline Dry matter & $92.97^{\mathrm{a}}$ & $69.63^{b}$ & $37.26^{\mathrm{c}}$ & $62.10^{\mathrm{b}}$ & $16.70^{\mathrm{d}}$ & 7.23 & $<0.01$ \\
\hline Crude protein & $89.06^{\mathrm{a}}$ & $80.71^{\mathrm{b}}$ & $80.53^{b}$ & $84.97^{\mathrm{ab}}$ & $49.45^{\mathrm{c}}$ & 3.83 & $<0.01$ \\
\hline Ash & $71.66^{\mathrm{a}}$ & $44.82^{b}$ & $20.87^{\mathrm{bc}}$ & $25.14^{\mathrm{bc}}$ & $8.74^{\mathrm{c}}$ & 6.95 & $<0.01$ \\
\hline Ether extract & $91.34^{\mathrm{a}}$ & $90.31^{\mathrm{a}}$ & $63.58^{\mathrm{c}}$ & $70.84^{\mathrm{b}}$ & $71.56^{\mathrm{b}}$ & 3.12 & $<0.01$ \\
\hline NDF & $86.72^{\mathrm{a}}$ & $68.02^{\mathrm{b}}$ & $29.81^{\mathrm{cd}}$ & $36.18^{c}$ & $17.98^{\mathrm{d}}$ & 7.03 & $<0.01$ \\
\hline $\mathrm{ADF}$ & 52.97 & 61.65 & 26.44 & 39.07 & 20.24 & 6.13 & 0.15 \\
\hline $\mathrm{ADL}$ & $67.82^{\mathrm{a}}$ & $28.90^{\mathrm{b}}$ & $15.98^{\mathrm{b}}$ & $32.76^{\mathrm{b}}$ & $18.89^{\mathrm{b}}$ & 6.18 & 0.02 \\
\hline Cellulose & 70.11 & 77.62 & 27.64 & 42.24 & 24.11 & 7.78 & 0.06 \\
\hline Hemicellulose & $93.71^{\mathrm{a}}$ & $83.92^{\mathrm{a}}$ & $33.18^{c}$ & $61.37^{\mathrm{b}}$ & $18.46^{\mathrm{d}}$ & 7.83 & $<0.01$ \\
\hline
\end{tabular}

a,b,c,dec means in the same row having different superscripts differed significantly at $\mathrm{p}<0.05$, SEM - Standard Error of Means, PKC - Palm kernel cake, BDG - Brewer's dried grain, WO - Wheat offal and RB - Rice bran

The results in Table 4 showed significant $(\mathrm{p}<0.05)$ effect of fibre feedstuffs on $\mathrm{pH}$ and short chain fatty acids (SCFAs) profile in the foregut and hindgut of pigs. The $\mathrm{pH}$ values of the digesta of pigs fed maize and fibre feedstuffs appear to increase across treatment groups. The $\mathrm{pH}$ values of digesta in the foregut in relation to the hindgut decreased by $12.63 \%, 14.22 \%, 15.08 \%$, $12.33 \%$ and $9.17 \%$ across treatment groups from maize to RB-fed pigs. The short chain fatty acids (acetic, propionic and butyric) concentration in the digesta of the foregut of pigs fed RB was the least $(p<0.05)$. The total SCFAs production in the digesta of pigs fed PKC and WO were fractionally ( $12.81 \%$ and $12.03 \%$ ) higher than those fed BDG diet. At the hindgut, digesta of pigs fed BDG had significantly $(\mathrm{p}<0.05)$ higher value of total SCFAs concentration while the values obtained from the digesta of pigs fed $\mathrm{WO}$ and $\mathrm{RB}$ were similar ( $p>0.05)$ but those on PKC diet 
Ogunjobi, Adeyemi and Akinfala

Table 4: Effect of fibre feedstuffs on the short chain fatty acids (SCFAs) profile and $\mathrm{pH}$ in the foregut and hindgut of growing pigs

\begin{tabular}{llllllll}
\hline Parameters & $\begin{array}{l}\text { Diets } \\
\text { Maize }\end{array}$ & PKC & BDG & WO & RB & SEM & p-values \\
\hline pH & & & & & & & \\
Small intestine & $6.49^{\mathrm{b}}$ & $7.03^{\mathrm{a}}$ & $7.16^{\mathrm{a}}$ & $6.73^{\mathrm{b}}$ & $7.20^{\mathrm{a}}$ & 0.09 & 0.01 \\
Large intestine & $5.67^{\mathrm{d}}$ & $6.03^{\mathrm{bc}}$ & $6.08^{\mathrm{b}}$ & $5.90^{\mathrm{c}}$ & $6.54^{\mathrm{a}}$ & 0.10 & 0.01 \\
Foregut & & & & & & & \\
Acetic acid $\left(\mathrm{C}_{2}\right)$ & $29.45^{\mathrm{a}}$ & $20.73^{\mathrm{c}}$ & $21.05^{\mathrm{c}}$ & $26.39^{\mathrm{b}}$ & $12.22^{\mathrm{d}}$ & 1.96 & $<0.01$ \\
Propionic acid $\left(\mathrm{C}_{3}\right)$ & $2.43^{\mathrm{a}}$ & $2.17^{\mathrm{a}}$ & $0.85^{\mathrm{b}}$ & $0.47^{\mathrm{c}}$ & $0.40^{\mathrm{c}}$ & 0.29 & $<0.01$ \\
Butyric acid $\left(\mathrm{C}_{4}\right)$ & $8.29^{\mathrm{a}}$ & $7.20^{\mathrm{b}}$ & $4.59^{\mathrm{c}}$ & $3.52^{\mathrm{d}}$ & $2.87^{\mathrm{e}}$ & 0.70 & $<0.01$ \\
Total SCFA & $40.17^{\mathrm{a}}$ & $30.10^{\mathrm{b}}$ & $26.48^{\mathrm{c}}$ & $30.37^{\mathrm{b}}$ & $15.48^{\mathrm{d}}$ & 2.65 & $<0.01$ \\
Hindgut & & & & & & & \\
Acetic acid $\left(\mathrm{C}_{2}\right)$ & $53.25^{\mathrm{b}}$ & $19.75^{\mathrm{d}}$ & $81.88^{\mathrm{a}}$ & $24.44^{\mathrm{c}}$ & $23.96^{\mathrm{c}}$ & 7.94 & $<0.01$ \\
Propionic acid $\left(\mathrm{C}_{3}\right)$ & $2.94^{\mathrm{b}}$ & $0.74^{\mathrm{c}}$ & $3.61^{\mathrm{a}}$ & $2.98^{\mathrm{b}}$ & $0.97^{\mathrm{c}}$ & 0.39 & $<0.01$ \\
Butyric acid $\left(\mathrm{C}_{4}\right)$ & $27.46^{\mathrm{a}}$ & $4.92^{\mathrm{c}}$ & $13.76^{\mathrm{b}}$ & $4.75^{\mathrm{c}}$ & $5.40^{\mathrm{c}}$ & 2.94 & $<0.01$ \\
Total SCFA & $83.65^{\mathrm{b}}$ & $25.40^{\mathrm{d}}$ & $99.24^{\mathrm{a}}$ & $32.16^{\mathrm{c}}$ & $30.33^{\mathrm{c}}$ & 10.31 & $<0.01$ \\
\hline
\end{tabular}

a,b,c,d,e means in the same row having different superscripts differed significantly at $\mathrm{p}<0.05$, SEM - Standard Error of Means, PKC - Palm kernel cake, BDG - Brewer's dried grain, WO - Wheat offal and RB - Rice bran

Correlation between cell wall components and SCFA production in the foregut and hindgut of pigs fed fibre feedstuffs are presented in Tables 5 and 6. Negative association was found between acetate, dietary ADF and cellulose concentration obtained in the foregut of pigs fed fibre feedstuff. Similarly, the total SCFA production in the foregut, dietary cellulose and NDF contents of fibre feedstuffs showed significantly negative relationships. This could explain the greater SCFA concentration in the digesta of pigs fed maize, WO and PKC diets which had lower ADF and cellulose components. In the hindgut, concentration of propionate and butyrate increased compared to those obtained in the foregut but there seems to be no relationship with fibre components.

Table 7 shows the effect of fibre feedstuffs on bacterial population in growing pigs. The ratio of Lactobacillus to total aerobe count in the digesta were $0.230 \%, 0.012 \%$, $0.030 \%, 4.480 \%$ and $0.012 \%$ in the foregut and $0.370 \%, 2.670 \%, 2.120 \%$, $8.920 \%$ and $0.000064 \%$ in the hindgut for Maize, PKC, BDG, WO and RB respectively. The ratios show the proportion of beneficial to pathogenic bacteria population. Of all the fibre feedstuffs, rice bran gave the poorer beneficial bacteria growth while WO promoted the fastest growth.

\section{Discussion}

The low arabinoxylan-oligosaccharide concentration in maize and WO could be attributed to the low acid detergent fibre (4.66 \% and $10.48 \%$ ) and neutral detergent fibre $(26.18 \%$ and $39.69 \%)$ as well as higher hemicellulose $(21.52 \%$ and 29.21 $\%)$ than cellulose contents. This result is consistent with earlier reports by Lu et al. (2000); Belanga-Reyes et al. (2011) and Jaworski et al. (2015). The authors evaluated the arabinoxylan concentration of cereal grains and its co-products, and found that those low in arabinoxylan concentration had lower proportion of NSP. The proximate contents obtained in this study except for the CP and CF of BDG and $\mathrm{RB}$ were lower than those reported for $\mathrm{PKC}, \mathrm{BDG}, \mathrm{WO}$ and $\mathrm{RB}$, respectively (Amaefule et al., 2009; Fatufe et al., 2016; Ghodrat et al., 2017). The higher CP and CF of BDG and RB could be due to 
Table 6: Correlation coe fficients between dietary fibre components and short -chain fatty acids (SCFAs) produced in the digesta obtained from the hindgut of pigs

\begin{tabular}{llllllllll}
\hline Items & \multicolumn{1}{c}{$\begin{array}{c}\text { Acetate Propionat } \\
\text { e }\end{array}$} & $\begin{array}{r}\text { Butyrate Total } \\
\text { SCFA }\end{array}$ & NDF & ADF & ADL & $\begin{array}{c}\text { Cellulose Hemicellulos } \\
\text { e }\end{array}$ \\
\hline Acetate & 1 & & & & & & & & \\
Propionate & 0.56 & 1 & & & & & & & \\
Butyrate & 0.31 & 0.53 & 1 & & & & & & \\
Total SCFA & $0.97^{* *}$ & $0.86^{*}$ & $0.74^{*}$ & 1 & & & & & \\
NDF & -0.07 & -0.48 & -0.55 & -0.26 & 1 & & & & \\
ADF & -0.21 & -0.69 & -0.50 & -0.36 & $0.96^{* *}$ & 1 & & & \\
ADL & -0.26 & -0.50 & -0.62 & -0.41 & $0.87^{* *}$ & $0.93^{* *}$ & 1 & & \\
Cellulose & -0.18 & -0.47 & -0.58 & -0.33 & $0.96^{* *}$ & $0.99^{* *}$ & $0.87^{* *} 1$ & \\
Hemicellulose & 0.52 & -0.34 & -0.05 & 0.45 & -0.22 & -0.48 & -0.50 & -0.46 & 1 \\
\hline
\end{tabular}

ADF, Acid Detergent Fibre; ADL, Acid Detergent Lignin; NDF, Neutral Detergent fibre; SCFA, Short Chain Fatty Acids

$* * \mathrm{P}<0.05$.

$* \mathrm{P}<0.10$

.Table 7: Effect of fibre feedstuffs on bacterial population in growing pigs (CFU/g digesta)

\begin{tabular}{lccccccc}
\hline & $\begin{array}{l}\text { Diets } \\
\text { Maize }\end{array}$ & PKC & BDG & WO & RB & SEM & p-value \\
\hline Foregut & & & & & & & \\
Total aerobes count $\left(\times 10^{9}\right)$ & $0.59^{\mathrm{d}}$ & $86.00^{\mathrm{a}}$ & $33.5^{\mathrm{c}}$ & $0.24^{\mathrm{d}}$ & $80.50^{\mathrm{b}}$ & 12.42 & $<0.01$ \\
Lactobaccillus count $\left(\times 10^{6}\right)$ & $1.35^{\mathrm{c}}$ & $10.40^{\mathrm{ab}}$ & $10.25^{\mathrm{ab}}$ & $10.75^{\mathrm{a}}$ & $10.05^{\mathrm{b}}$ & 1.21 & $<0.01$ \\
Hindgut & & & & & & & \\
Total aerobes count $\left(\times 10^{9}\right)$ & $0.95^{\mathrm{b}}$ & $0.41^{\mathrm{b}}$ & $0.51^{\mathrm{b}}$ & $0.013^{\mathrm{b}}$ & $162.00^{\mathrm{a}}$ & 21.54 & $<0.01$ \\
Lactobacillus $\operatorname{count}\left(\times 10^{6}\right)$ & $3.55^{\mathrm{c}}$ & $10.95^{\mathrm{ab}}$ & $10.80^{\mathrm{ab}}$ & $11.60^{\mathrm{a}}$ & $10.30^{\mathrm{b}}$ & 1.00 & $<0.01$ \\
\hline
\end{tabular}

a,b,c,d means in the same row having different superscripts differ at $\mathrm{p}<0.05$, SEM - Standard Error of Means, CFU- Colony forming unit, g - gram, PKC - Palm kernel cake, BDG - Brewer's dried grain, WO - Wheat offal and RB - Rice bran

fermentation method of production from brewery and highly fibrous nature of the outer covering respectively. The overall variations $(p<0.05)$ observed in the proximate composition of fibre feedstuffs and maize could be attributed to the sources and methods of extraction/ processing of the feedstuffs.

The NDF contents of $\mathrm{WO}$ and RB obtained in this study were higher compared with the values $(33.6 \%$ and $44.0 \%$ respectively) reported by Zhao et al. (2019) although the ADL and ADF contents of WO were similar to the values obtained in this study while that of RB differed significantly $(p<0.05)$. The variations observed in the cell wall components of the feedstuffs could be attributed to the processing/extraction methods or varietal differences. Similarly, the apparent nutrient digestibility of fibre feedstuffs varied among treatment groups. These variations could be due to differences in the extent of lignification, physico-chemical properties and processing methods (Johansen et al., 1997; Le Goff et al., 2003). The poor digestibility coefficient obtained for pigs on BDG and RB could be attributed to the low digestibility of cell wall fractions importantly the ADF, ADL and cellulose. Similar findings were reported by Le Goff and Noblet (2001); Hogberg and Lindberg (2006) who evaluated the digestibility of dietary energy feed in weaning and growing pigs and found that digestibility of fibre feeds is 


\section{Ogunjobi, Adeyemi and Akinfala}

influenced by the solubility of cell wall fractions. Of all the fibre feedstuffs, RB had the least apparent nutrient digestibility coefficient, SCFA and total SCFA concentrations. This may be due to the poor fermentability and digestibility of $\mathrm{RB}$ in the foregut. However, in the hindgut, there was sparingly improved degradation which was evident through increased production of SCFA and total SCFA concentrations. The poor SCFA production from digesta of pigs fed $\mathrm{PKC}$ in the hindgut than foregut could mean that substantial proportion of the fibre components of PKC were less digested in the hindgut (Jha et al., 2010; Jha and Leterme, 2012) or that PKC contained higher lignin content which resists the activity of cellulolytic bacteria. Notably, the results of this study showed that pigs fed the fibre feedstuff that gave the least lignin digestibility coefficient produced the greatest SCFA while higher SCFA production from digesta of pigs fed maize could be due to its high quantity of soluble NSP (hemicellulose) (Davidson and McDonald, 1998; Zhao et al., 2020). The fibre components including the non-starch polysaccharides had been reported by Pluske et al. (2001) as one of the determinants of the nutritive value of feedstuffs for monogastrics. Also, studies by Classen and Bedford (1991) and Choct (1997) found that high NSP contributed to increased digesta viscosity, bulk and viscosity of the intestinal contents with an overall effect of decreased nutrient digestibility. There were significant linear relationships between crude fibre $(\mathrm{CF})$, neutral detergent fibre (NDF) and digesta $\mathrm{pH}$ in the gut. As the CF and NDF contents of the diets increased, the $\mathrm{pH}$ decreased linearly. This finding is consistent with the reports of the studies by Freire et al. (2000) and Ma et al. (2002) who found decreased $\mathrm{pH}$ in the hindgut (caecum and colon) of piglets fed high fibre feedstuff. The CF and NDF contents of the diets also produced similar relationships with total SCFAs production in the fore gut although this effect could not be verified in the individual (acetic, propionic and butyric) SCFAs. However, there was no influence of CF or NDF on SCFAs production in the hind gut. Diet and intestinal bacteria population in the gut had inverse relationships with colonic $\mathrm{pH}$. High fibre diets increased the quantity of SCFAs produced, with a $\mathrm{pH}$ lowering effect on the colon. The reduction in $\mathrm{pH}$ alters the composition of colonic microbiota and SCFAs production. This is because as the colonic microbiota absorbs most of the SCFAs produced in exchange for bicarbonate, the luminal $\mathrm{pH}$ falls owing to the neutralizing ability of bicarbonate (Cummings et al., 1987; Annison et al., 2003). As the digestion proceeds from the proximal to the distal colon, the concentration of SCFA declines resulting in an increase in $\mathrm{pH}$ from the caecum to the rectum; along the hind gut. The fall in $\mathrm{pH}$ values from the fore gut to the hind gut may be due to increased SCFAs production. This finding was similarly reported by Besten et al. (2013). The $\mathrm{pH}$ lowering effects may have contributed to a change in gut microbiota composition thereby inhibiting proliferation of pathogenic bacteria such as Clostridia and Enterobacteria, and consequently promoting the growth of beneficial bacteria such as Lactobacilli. The result of this study revealed negative correlation between acetate, dietary ADF and cellulose. Similar relationships were also found between total SCFA production, cellulose and NDF contents of fibre feedstuffs. This could explain the greater SCFA concentration in the digesta of pigs fed maize, WO and PKC diets which contained lower ADF and cellulose components. The results of correlation of SCFA production and dietary fibre components could be attributed to the ease 
of cleavage by homogenous polysaccharides to form the corresponding monosaccharides of which ADF is a major component (Mu et al., 2014). Also, the soluble dietary fibre content of the feedstuffs tended to correlate with the population of beneficial bacteria expressed as a proportion of total aerobe counts in the fore and hind guts of the experimental pigs. The variations in bacterial population could be due to the different types of DF and the fermentable components at the gut environment of the experimental pigs. This together with the $\mathrm{pH}$ could be the reason for the greater total SCFA production in the digesta of pigs fed WO and BDG within the fore and hind guts. Studies (Bach Knudsen et al., 2012; Jha et al., 2012) have shown that population and activity of gastrointestinal microbiota is largely influenced by types of diet, hence DF could significantly influence gut environment. The total aerobe and Lactobacillus count obtained in this study for PKC diet were higher compared to the values $(1.29 \pm 0.11$ $\times 10^{10}$ and $1.46 \pm 0.18 \times 10^{7}$ respectively) reported by Jahromi et al. (2016). The observed variations however may be due to the low inclusion level of $1 \mathrm{~g} / \mathrm{Kg}$ used in the study. Also, the increased production of Lactobacillus in the hindgut compared with the foregut could be suggestive that DF was mainly degraded in the hindgut. This lends credence to the earlier observation that more SCFA were produced in the hindgut than foregut. The activity of Lactobacillus on fibre diets produced primarily acetate which could contribute to increased acidification of gut environment; creating a competitive ability for the Lactobacillus at the expense of pathogenic bacterial species within the gut (Turnbaugh et al., 2006; Pessione, 2012). It is obvious in this study that sources of fibre determined the concentration of SCFA production. The lower digestibility of NDF and ADF for RB could be implicit in its low
SCFA production both in the fore and hind guts of pigs as well as its poor Lactobacillus count. This is consistent with the reports by Freire et al. (2000); Jha and Berrocoso (2015) that digestibility of NDF and ADF of fibre feedstuffs is related to SCFA production in the gut of pigs. Conversely, WO promoted the highest lactobacillus growth in relation to total aerobe count. This observation could be attributed to the substantial quantity of soluble than insoluble NSP in WO diet which could influence gut health and promote growth of beneficial microbes (Wellock et al., 2007). Similar observation was reported by Van Laere et al. (2000) and Mirande et al. (2010) who evaluated different fibre feedstuffs with pigs and found that wheat bran diet enhanced the fastest Lactobacilli growth. Similarly, increased propionate and butyrate concentrations in the hindgut could jointly be responsible for promoting normal colonocytes, thus, controlling the growth and proliferation of pathogenic bacterial, as well as maintaining healthy gut microbiota (Lupton, 2004; Minucci and Pelicci, 2006). Also, Lactobacillus (a gut probiotic) could have prevented adhesion of enteric pathogens to host (Varma et al., 2010) thus, contributes to boosting the immune function and welfare of the experimental pigs.

\section{Conclusion}

Based on the findings of the study, Palm kernel cake could be incorporated in diets for growing pigs to enhance the a rabinoxylan-oligos accharide concentration. Also, Palm kernel cake and wheat offal enhanced more SCFA production at the foregut while brewer dried grains enhanced more production at the hindgut and as such, the three fibre feedstuffs could be included in diets for growing pigs. However, for better stimulation of Lactobacilli growth and 
inhibition of pathogens, wheat offal could be considered for inclusion in diets of growing pigs.

\section{References}

Amaefule, K. U., Abasiekong, S. F., Ibe, S. N. and Onwwudike, O. C. 2009. Digestibility and nutrient utilization of some agro-industrial by-products fed to growing pigs in the humid Tropics. Pakistan Journal of Nutrition, 8(4), 355 360.

Anderson, D. B., McCracken, V. J., Aminov, R. I., Simpson, J. M., Mackie, R. I., Verstegen, M. W. A. and Gaskins, H. R. 2000. Gut microbiology and growthpromoting antibiotics. Pig News Information, $20,1115 \mathrm{~N}-1122 \mathrm{~N}$.

Annison, G., Illman, R. J. and Topping, D. L. 2003. Acetylated, propionylated or butyrylated starches raise large bowel short chain fatty acids preferentially when fed to rats. Journal of Nutrition, 133, 3523 - 3528.

AOAC 2005. Official methods of analysis. $18^{\text {th }}$ edition. Published by the Association of Official Analytical Chemists; Arlington, Virginia.

Bach Knudsen, K. E., Hedemann, M. S. and Laerke, H. N. 2012. The role of carbohydrates in intestinal health of pigs. Animal Feed Science and Technology, 173:41-53.

Bedford, M. R. and Schulze, H. 1998. Exogenous enzymes for pigs and poultry. Nutrition Research Reviews, 11(1), 91-114.

Bindelle, J., Pieper, R., Leterme, P., Rossnagel, B. and Van Kessel, A. G. 2010. Changes in intestinal microbial ecophysiology as related to the carbohydrate composition of barleys and oats cultivars in an in vitro model of the pig gastrointestinal tract. Livestock Science, 133,151-153.

Bouhnik, Y., Raskine, L., Simoneau, G., Vicaut E., Neut, C., Flourié, B., Brouns, F. and Bornet, F. R. 2004. Capacity of non-digestible carbohydrates to stimulate bifidobacteria in healthy humans. American Journal of Clinical Nutrition, 80, 1658-1664.

Choct, M. 1997. Feed Non-Starch Polysaccharides: Chemical Structure and Nutritional Significance. Feed Milling International, June Issue; 13-26.

Classen, H. L. and Bedford, M.R. 1991. The use of enzyme to improve the nutritive value of poultry feeds. In: Haresign, W. and Cole, D.J.A. (eds.) Recent Advances in Animal Nutrition (pp 95-116) Butterworth, London.

Cromwell, G. L. 2000. Why and how antibiotics are used in swine production. In: Schook, L. B. (ed.) A proceedings of the Pork Industry Conference on Addressing Issues of Antibiotic Use in Livestock Production (pp 7 - 27) University of Illinois, Urbana.

Cummings, J. H., Pomare, E. W., Branch, W. J., Naylor, C. P. and Macfarlane G. T. 1987. Short chain fatty acids in human large intestine, portal, hepatic and venous blood. Gut, 28, 1221 1227.

Davidson, M. H. and McDonald, A. 1998. Fibre: forms and functions. Nutrition Research, 18, 617-624.

den Besten, G., van Eunen, K., Groen, A. K., Venema, K., Reijngoud, D. J. and Bakker, B. M. 2013. The role of short-chain fatty acids in the interplay between diet, gut microbiota, and host energy 
metabolism. Journal of Lipid Research, 54, 2325-2340.

EFSA 2009. Analysis of the baseline survey on the prevalence of methicillinresistant Staphylococcus aureus (MRSA) in holdings with breeding pigs, in the EU, 2008. Part A MRSA prevalence estimates. Journal of European Food Safety Authority, 7(11), 13 - 76

Fatufe, A. A., Adesehinwa, A. O. K. and Ajayi, E. 2016. Comparative utilisation of two dietary fibre sources supplemented with directfed microbials in growing pigs. Journal of Animal Production Research, 28(1), 299-308.

Freire, J. P. B., Guerreiro, A. J. G., Cunha, L. F. and Aumaitre, A. 2000. Effect of dietary fibre source on total tract digestibility, caecum volatile fatty acids and digestive transit time in the weaned piglet. Animal Feed Science and Technology, 87, 71-83.

Gancarcikova, S., Buleca, V., Zitnan, R., Nemcova, R., Scirankova, L., Koscova, J., Mudronova, D., Hluchy, M. and Huska, M. 2009. Postnatal morphological development and production of short-chain fatty acids in the digestive tract of gnotobiotic piglets. Veterinarni Medicina, 54(4), 156-168.

Gerritsen, R., van der Aar, P. and Molist, F. 2012. Insoluble non-starch polysaccharides in diets for weaned piglets. Journal of Animal Science, 90, 318-320.

Ghodrat, A., Yaghobfar, A ., Ebrahimnezhad, Y., Shahryar, H. A. and Ghorbani, A. 2017. In vitro binding capacity of organic (wheat bran and rice bran) and inorganic (perlite) sources for $\mathrm{Mn}$, $\mathrm{Zn}, \mathrm{Cu}$ and Fe. Journal of Applied
Animal Research, 45(1), 80-84.

Gibson, G. R. and Roberfroid, M. B. 1995. Dietary modulation of the human colonic microbiota: introducing the concept of prebiotics. The Journal of Nutrition, 125, 1401-1412.

Grizard, D. and Barthomeuf, C. 1999. Non-digestible oligosaccharides used as prebiotic agents: mode of production and beneficial effects on animal and human health. Reproduction Nutrition Development, 39, 5 - 6.

Hogberg, A. and Lindberg, J. E. 2004. Infiuence of cereal non-starch polysaccharides on digestion site and gut environment in growing pigs. Livestock Production Science, 87, 121-130.

Jahromi, M. F., Liang, J. B., Abdullah, N., Goh, Y. M., Ebrahimi, R. and Shokryazdan, P. 2016. Extraction and Characterization of Oligosaccharides from Palm Kernel Cake as Prebiotic. BioResources, 11(1), 674-695.

Jaworski, N. W., Larke, H. N., Bach Knudsen, K. E. and Stein, H. H. 2015. Carbohydrate composition and in vitro digestibility of dry matter and non-starch polysaccharides in corn, sorghum, and wheat and coproducts from these grains. Journal of Animal Science, 93, 1103-1113.

Jha, R. and Leterme, P. 2012. Feed ingredients differing in fermentable fibre and indigestible protein content affect fermentation metabolites and faecal nitrogen excretion in growing pigs. Animal $6, \quad 603-612$. https://doi.org/10.1017/S1751731 111001844.

Jha, R., and Berrocoso, J. D. 2015. Review: Dietary fiber utilization 
and its effects on physiological functions and gut health of swine. Animal, 9(9), 1441-1452

Jha, R., Owusu-Asiedu, A., Simmins, P. H., Pharazyn, A. and Zijlstra, R. T. 2012. Degradation and fermentation characteristics of wheat coproducts from fiour milling in the pig intestine, studied in vitro. Journal of Animal Science, E-suppl. 90, 173-175.

Jha, R., Rossnagel, B., Pieper, R., Van Kessel, A., and Leterme, P. 2010. Barley and oat cultivars with diverse carbohydrate composition alter ileal and total tract nutrient digestibility and fermentation metabolites in weaned piglets. A n i ma 1, 4, $724-731$. http://doi.org/10.1017/S17517311 09991510.

Johansen, H. N., Bach Knudsen, K. E., Wood, P. J. and Fulcher, R. G. 1997. Physico-chemical properties and the degradation of oat bran polysaccharides in the gut of pigs. Journal of the Science of Food and Agriculture, 73, 81-92.

Jouany, J. P. 1982. Volatile fatty acid and alcohol determination in digestive contents, silage juices, bacterial cultures and anaerobic fermentor contents. Science des Aliments, 2, 131-144.

Kalantar, M., Khajali, F., Yaghobfar, A., Pourreza, J. and Akbari, M. R. 2014. Broiler chicken growth performance, ileal microbial population and serum enzyme activity affected by dietary source of non-starch polysaccharides as supplemented with or without enzymes. Global Journal of Animal Scientific Research, 2, 312.

Le Goff, G. and Noblet, J. 2001. Effect of dietary fibre on the energy value of feeds for pigs. Animal Feed Science and Technology, 90, 3552.

Le Goff, G., Noblet, J. and Cherbut, C. 2003. Intrinsic ability of the faecal microbial flora to ferment dietary fibre at different growth stages of pigs. Livestock Production Science, 81, 75-87.

Lu, Z. X., Walker, K. Z., Muir, J. G., Mascara, T. and O'Dea, K. 2000. Arabinoxylan fibre, a by-product of wheat flour processing, reduces the postprandial glucose response in normoglycemic subjects. America Journal of Clinical Nutrition, 71, 1123 - 1128.

Ma, Y., Li, D., Qiao, S. Y., Huang, C. H. and Han, I. K. 2002. The Effects of Fibre Source on Organ Weight, Digesta $\mathrm{pH}$, Specific Activities of Digestive Enzymes and Bacterial Activity in the Gastrointestinal Tract of Piglets. AsianAustralasian. Journal of Animal Science, 15(10), 1482-1488

Minucci, S., and Pelicci, P. G. 2006. Histone deacetylase inhibitors and the promise of epigenetic (and more) treatments for cancer. Nat. Rev. Cancer 6, 38-51

Mirande, C., Kadlecikova, E., Matulova, M, Capek, P, BernalierDonadille, A., Forano, E., and Bera-Maillet, C. 2010. Dietary fibre degradation and fermentation by two xylanolytic bacteria Bacteroides xylanisolvens XBIAT and Roseburia intestinalis XBOB4 from the human intestine. Journal of Applied Microbiology, 109, 451 -460 .

Mu, C., Zhang, L., He, X., Smidt, H., and Zhu, W. 2014. Dietary fibres modulate the composition and activity of butyrate-producing bacteria in the large intestine of 
suckling piglets. Antonie van Leeuwenhoek, 110, 687-696. https://doi.org/10.1007/

Nielsen, T. S., Laerke, H. N., Theil, P. K., Sørensen, J. F, Saarinen, M., Forssten, S. and Bach-Knudsen, K. E. 2014. Diets high in resistant starch and arabinoxylan modulate digestion processes and SCFA pool size in the large intestine and faecal microbial composition in pigs. British Journal of Nutrition, 112, 1837-1849.

Patterson, J. A. 2005. Prebiotic Feed Additives: Rationale and Use in Pigs. Advances in Pork Production, 16: 149-159

Pessione, E. 2012. Lactic acid bacteria contribution to gut microbiota complexity: lights and shadows. Frontiers in cellular and infection microbiology, 2(86), 1 - 15

Pieper, R., Jha, R., Rossnagel, B., Van Kessel, A. G., Souffrant, W. B. and Leterme, P. 2008. Effect of barley and oat cultivars with different carbohydrate compositions on the intestinal bacterial communities in weaned piglets. FEMS Microbiology Ecology, 66, 556-566.

Pluske, J.R., Kim, J.C., McDonald, D.E., Pethick, D.W., Hampson, D.J. 2001. Non-starch polysaccharides in the diets of young weaned piglets. In: Varley, M.A., Wiseman, J. (Eds.), The Weaner Pig: Nutrition and Management (pp. 81-112). CABI Publishing, Wallingford.

Roberfroid, M. B., Bauer, E. and Mosenthin R. 2001. Pro- and prebiotics in pig nutrition potential modulators of gut health. Journal of Animal and Feed Sciences, 10, 47-56.

SAS 2009. SAS User's Guide, version 9.1 for windows, Statistical Analysis Systems Institute, Inc.,Cary, NC, U.S.A

Shim, S. B., Verstegen, W. A., Kim, I. H., Kwon, O. S. and Verdonk, J. M. A. J. 2005. Effects of feeding antibiotic-free creep feed supplemented with oligofructose, probiotics or synbiotics to suckling piglets increases the preweaning weight gain and composition of intestinal microbiota. Archives of Animal Nutrition, 59, 419-27.

Tuohy, K. M., Rouzaud, G. C. M., Bruck, W. M. and Gibson, G. R. 2005. Modulation of the human gut microflora towards improved health using prebiotics-assessment of efficacy. Current Pharmaceutical Design, 11, 7590.

Turnbaugh, P. J., Ley, R. E., Mahowald, M. A., Magrini, V., Mardis, E. R., and Gordon, J. I. 2006. An obesity-associated gut microbiome with increased capacity for energy harvest. Nature, 444, 1027-1031. https://doi.org/10.1038/nature054 14.

Van Laere, K.M., Hartemink, R., Bosveld, M., Schols, H. A. and Voragen, A. G. 2000 . Fermentation of plant cell wall derived polysaccharides and their corresponding oligosaccharides by intestinal bacteria. Journal of Agriculture, Food and Chemistry, 48, 1644 - 1652.

Van Soest, P. J., Robertson, J. B. and Lewis, B. A. 1991. Carbohydrate methodology, metabolism and nutritional implications in dairy cattle. Journal of Dairy Science, 74, 3583-3597.

Varma, P., Dinesh, K. R., Menon, K. K., and $B$ is w a s, R. 2010 . 


\section{Ogunjobi, Adeyemi and Akinfala}

Lactobacillus fermentum isolated from human colonic mucosal biopsy inhibits the growth and adhesion of enteric and foodborne pathogens. Journal of Food Science, 75, M546-M551. https://doi.org/10.1111/j.17503841.2010.01818.x.

Vondruskova, H., Slamova, R., Trckova, M., Zraly, Z. and Pavlik, I. 2010. Alternatives to antibiotic growth promoters in prevention of diarrhoea in weaned piglets: a review. Veterinarni Medicina, 55(5), 199-224.

Wang, J. J., Garlich, J. D. and Shih, J. C. H. 2005. Beneficial effects of Versazyme, a Keratinase feed additive, on body weight, feed conversion, and breast yield of broiler chickens. Poultry Science Research, 15, 544-550.

Wellock, I. J., Houdijk, J. G. M. and Kyriazakis, I. 2007. Effect of dietary non-starch polysaccharide solubility and inclusion level on gut health and the risk of post weaning enteric disorders in newly weaned piglets. Livestock Science, 108, 186-189.
Williams, B. A., Verstegen, M. W. A. and Tamminga, S. 2001. Fermentation in the large intestine of singlestomached animals and its relationship to animal health. Nutrition Research Reviews, 14, 207-227.

Zhao, J., Bai, Y., Tao, S., Zhang, G., Wang, J., Liu, L. and Zhang, S. 2019. Fibre-rich foods affected gut bacterial community and shortchain fatty acids production in pig model. Journal of Functional Foods, 57, 266-274

Zhao, J., Bai, Y., Zhang, G., Liu, L. and Lai, C. 2020. Relationship between Dietary Fibre Fermentation and Volatile Fatty Acids' Concentration in Growing Pigs. Animals, 10, 263, http://doi:10.3390/ani10020263

Received: $16^{\text {th }}$ October, 2020 Accepted: $8^{\text {th }}$ February, 2021 